\title{
Causing death or allowing to die? Developments in the law
}

\author{
Pamela R Ferguson University of Dundee, Dundee, Scotland
}

\begin{abstract}
Several cases which have been considered by the courts in recent years have highlighted the legal dilemmas facing doctors whose decisions result in the ending of a patient's life. This paper considers the case of Dr Cox, who was convicted of attempting to murder one of his patients, and explores the roles of motive, diminished responsibility and consent in cases of "mercy killing". The Cox decision is compared to that of Tony Bland and fanet fohnstone, in which the patients were in a persistent vegetative state.

In all three cases, the doctors believed that their patients' quality of life was so poor that their continued existence was of no benefit to them, and decided that their lives should not be unduly prolonged, yet the doctor who was prosecuted was the one whose dying patient had requesied that her death be hastened. The paper examines the law's seemingly contradictory approaches to such cases.
\end{abstract}

\section{The Cox case ${ }^{1}$}

In 1992 Dr Nigel Cox, a consultant rheumatologist, was convicted of attempting to murder Mrs Lillian Boyes, one of his patients. Mrs Boyes had been terminally ill with rheumatoid arthritis; she suffered from septicaemia and had abscesses and ulcers on her limbs. Her heart was calcified, her lungs were malfunctioning. She had gangrene and a number of fractures of the lumbar spine. There is no doubt that Mrs Boyes was in excruciating pain. Dr Cox had administered heroin in an attempt to alleviate her suffering, but to no avail. It was then that he injected her with potassium chloride, and she died shortly thereafter. Many people praised Dr Cox for his humane act, and expressed the hope that they might be treated similarly by their doctors if they were in equally severe pain and in the final stages of a terminal illness. It is clear, however, that the criminal law views his behaviour quite differently since he was charged with murder and, the

\section{Key words}

Euthanasia; murder; law; Bland; Johnstone; Cox; act; omission. body having been cremated before a conclusiv cause of death could be established, convicted ${ }^{2} \mathrm{~g}$ attempted murder. ${ }^{2}$

\section{Murder, motive and diminished responsibility}

Crimes can be analysed in terms of two aspects, first the "forbidden situation" or what the accused actually $\mathrm{did}$, and secondly the accused person's state of mind at the time. The "forbidden situation" for murder is that the accused person caused the deat of another person. In English law the state of ming which makes such a killing murder is termed "matice aforethought" . This rather misleading term means no more than that the accused person must haves intended to cause death. ${ }^{3}$ Clearly, Dr Cox intende to cause the death of Lillian Boyes.

It may be felt that Nigel Cox should not have been treated as a potential murderer because his was a "mercy killing". As the president of the General Medical Council (GMC) stated in reprif manding Dr Cox but not striking him off the medical register, the doctor had "acted in goo $\overline{\text {. }}$ faith" in what he had felt to be the best interests of Mrs Boyes. The reasons why a person does a pare ticular act is regarded in law as his or her motive Dr Cox was undoubtedly motivated by a desire te end his patient's suffering. One might believe that is one thing to kill a person out of greed or hate, but quite another to kill on compassionate grounds However, the law is not generally concerned with person's motive. This is illustrated by the case of Dr Leonard Arthur who was tried for the murder of a Down's syndrome baby, in 1981. The distinction between "motive" and "intention" was described by the judge in that case as follows:

"It may be that somebody faced with an ageing relative who was suffering from an incurably painfitb disease, from the best motive in the world, decides tô put a pillow over the poor soul's head so that he $\vec{f}$ she dies. That would mean that there was then an intent to kill by putting a pillow over the head. The motive, of course, would have been the kindest and the best". 4 
Hence the criminal law is generally only interested in a person's intent; if the accused intentionally killed his or her victim then this is the crime of murder. Since the sentence for murder is the mandatory one of "life imprisonment," a person's motives will have little bearing on the disposal of such a case. As already noted, Dr Cox was convicted of attempted murder, rather than murder, and it was this lesser charge which gave the court a wide range of sentencing options. Dr Cox received a twelve months suspended jail sentence. If the prosecution had been able to establish that the injection of the potassium chloride had been the cause of Mrs Boyes's death, then Dr Cox would have been sentenced to life imprisonment, irrespective of any good motive which he might have had. ${ }^{5}$

A conviction for manslaughter on a murder charge may occur if a jury accepts that the accused person acted in a state of "diminished responsibility". This is defined by section 2(1) of the Homicide Act 1957 as:

"such abnormality of mind ... . as substantially impaired [the accused person's] mental responsibility for his acts or omissions in doing or being a party to the killing."

A jury may be prepared to accept that the grief of watching a close relative endure the pain of a terminal illness may have tipped the balance of the accused's mind, hence diminishing that person's responsibility. More pragmatically, a jury may convict of manslaughter due to reluctance to brand as a murderer a person who has committed a mercy killing of a relative. A finding of "diminished responsibility" is simply the legal mechanism by which such a result is achieved. In theory, members of the medical profession could attempt to argue that their responsibility ought to be regarded as "diminished" because they too had become emotionally distraught by a patient's suffering. This may, however, be difficult to establish, and in practice it is unlikely that a doctor would wish to be branded as someone who had suffered from an "abnormality of the mind".

\section{Consent, acts and omissions, and the doctrine of double effect}

Might the fact that a patient consents to the ending of his or her life provide a doctor with a defence? Patients do require to consent to medical treatment before such treatment is lawful, and a doctor who treats a patient without the latter's consent may face prosecution for battery, or a civil action for damages. It follows from this that patients may decline further treatment, and their decisions require to be respected by their doctors. ${ }^{6}$ There is little doubt that Mrs Boyes wanted to die and that she had requested Dr Cox to end her suffering. However, although one can refuse further treatment, one cannot consent to being killed; even where a patient pleads for death, a doctor who intentionally kills will have no defence of consent to a murder charge. This also illustrates the distinction which the law draws between acts and omissions to act. A person who causes death by omitting to act (for example, by not providing treatment) will not necessarily be held liable for this, even where death results. In contrast to this, a person who acts to cause death will be liable, and the patient's consent is no defence. This acts/omissions doctrine is discussed further, below.

The law has, however, accepted that if there is no other way of alleviating pain, a doctor may be justified in administering a pain-killing drug to a patient whose death is imminent, even if the doctor knows that the drug might have the incidental effect of hastening death. This principle, known as the doctrine of double effect, arose in the trial of Dr John Bodkin Adams in $1957 .{ }^{7}$ Dr Adams was tried for the murder of an 81-year-old woman who had suffered a stroke. The prosecution alleged that he had administered such massive quantities of heroin and morphine that he must have known that these drugs would kill his patient. According to the Crown, if Dr Adams knew that the drugs would result in the death of his patient then he could be said to have intended to kill her. However, the trial judge, Lord Devlin, directed the jury as follows:

"If the first purpose of medicine - the restoration of health - can no longer be achieved, there is still much for a doctor to do, and he is entitled to do all that is proper and necessary to relieve pain and suffering, even if measures he takes may incidentally shorten life". 8

It seems then, that a doctor whose primary intention is to relieve pain, rather than to end life, may have a defence. In 1990 Dr Stephen Lodwig was charged with the murder of one of his patients. Dr Lodwig had injected the patient with a mixture of potassium chloride and lignocaine. In his defence, evidence was given that this mixture had the potential to ease pain; it was not possible, therefore, for the prosecution to establish beyond a reasonable doubt that the doctor's intention was to kill the patient, rather than the pain. ${ }^{9}$ In the Cox case, it seems to have been conceded by the defence that the potassium chloride was not administered for pain- killing purposes. The moral seems to be that a doctor should use some form of pain-killer, so that the prosecution will find it very difficult, if not impossible, to exclude the possibility of "double effect".

\section{Tony Bland ${ }^{10}$ and Janet Johnstone ${ }^{11}$}

The circumstances of both of these cases have been well documented: a victim of the Hillsborough disaster, Mr Bland had been in a persistent vegetative state (PVS) following that tragedy in April 1989, 
and Mrs Johnstone had been in PVS for four years following a drug overdose. Both had been kept alive by artificial nutrition and hydration, and their relatives had asked their doctors to remove the feeding tubes and allow them to die. Bland was the first PVS case to come before an English court, and Johnstone was the first to be heard by a court in Scotland. ${ }^{12}$

As already noted, the "state of mind" required for a charge of murder is an intention to bring about the death of another person. In the Bland case, Lord Lowry stated: ". . . the intention to bring about the patient's death is there. ..." This was also accepted by Lord Browne-Wilkinson - as he put it "the whole purpose of stopping artificial treatment is to bring about the death of Anthony Bland". What of the "forbidden situation"? Lord Browne-Wilkinson accepted that the removal of the nasogastric tube would be a "positive act". Despite this he held:

"If, instead of removing the nasogastric tube, it was left in place but no further nutrients were provided for the tube to convey to the patient's stomach, that would not be an act of commission ... essentially what is being done is to omit to feed or to ventilate: the removal of the nasogastric tube or the switching off of a ventilator are merely incidents of that omission. . ..."13

The forbidden situation for murder, that is, the causing of death, can be brought about by a positive act, such as by administering drugs which kill a patient, or by an omission to act - by failing to treat or feed a person. For example, if a parent were to neglect to feed his or her child and that child were to die as a result, the parent would be held criminally liable for this. The existence of a legally recognised duty of care between the parties is crucial here. Any omission to fulfil these duties which causes death may result in the parents being prosecuted for murder, or at least, for manslaughter. Doctors owe their patients a similar duty of care, hence a doctor who fails to treat a patient may be said to be in a position akin to that of a parent who neglects a child. As Lord Hope, then Lord President of the Court of Session, stated in the Johnstone case: "A deliberate omission which causes death may ... expose the medical practitioner to the allegation that his conduct was criminal". ${ }^{14}$

As already noted, once a competent patient refuses to consent to future treatment, a doctor is relieved of any duty to continue this treatment. Patients may give clear instructions, prior to becoming incapacitated, that they wish certain forms of treatment to cease should their condition deteriorate beyond a certain stage. This may be done in an "advance directive" or "living will". However, in many cases, patients have suffered acute injuries and there is little prospect of their having made written provision for this. Neither $\mathrm{Mr}$ Bland nor Mrs Johnstone had given explicit instructions of this nature. One could not thereforem say that treatment was being withdrawn or withheld $\vec{E}$. with the agreement of the patient. In such a situas? tion the patient is not in a position to relieve the doctors of their duty of care. If this duty is consid? ered to be a continuing one, its breach could resule in legal liability.

Where a patient is unable to decide for him of herself the law allows the doctors to determine whether there is any medical benefit to be obtained from continuation of a treatment. There is no lega $b$ obligation on a doctor to continue with treatmentwhich is futile. Is continued treatment of benefit tow the PVS patient? Lord Hope stated in Johnstone thas “. . . existence in a vegetative state with no prospecto of recovery is by a large body of informed and responsible medical opinion regarded as not being aंs benefit". ${ }^{15}$ As is well known, the House of Lords authorised the withdrawal of feeding in the Blando case, and this was applied to Scots law in the Johnstone case, Lord Hope stating:

"I can see no relevant distinction between the way in which the underlying principle was applied in [the Bland] case and the question which has to beㅁ decided here in the case of Mrs Johnstone". ${ }^{15}$

In granting the declarations in Bland and Johnsto that cessation of artificial hydration and nutritione would not be unlawful, the courts categorised artifficial feeding as a form of treatment. This allowech them to hold that a doctor is not under a duty ton continue this where it is incapable of improving a patient's chances of recovery, at least so far as PVSO patients are concerned. Professor Jennett has contended that:

"The argument that food and water are basic needs that should never be denied rests on their normallyo assuaging the ravages of hunger and thirst and $B$. enabling a life that is enjoyed to continue. Neitheri applies to vegetative patients, and the symbolic sig nificance of feeding is therefore lost". ${ }^{16}$

Nevertheless, even if it is the case that a PVS patiento does not suffer pain or discomfort from having fooo and water withdrawn, starving such patients to deathp is bound to be distressing to the relatives, and to the medical staff who are involved in their care.

\section{Law and morals}

As we have seen, the law draws a rigid distinction between "acts" and "omissions to act". It is however, not clear that this necessarily reflects a fun $\overline{0}$ damental moral difference, in all circumstances $\vec{\Phi}$ Lord Goff recognised this in the Bland case; hष्ठ conceded that the drawing of a distinction between the giving of a lethal injection (an act) and the discontinuation of treatment (an omission) "may 
lead to a charge of hypocrisy". Lord BrowneWilkinson also found the distinction between acts and omissions to be a difficult one. He said:

"How can it be lawful to allow a patient to die slowly, though painlessly, over a period of weeks from lack of food but unlawful to produce his immediate death by a lethal injection . . . ? I find it difficult to find a moral answer to that question."17

It is true that, in general, it is considered of greater moral blameworthiness actively to kill another person than to omit to act to prevent another's death. Where, however, death may be said to be the desired outcome from the point of view of the "victim" then the position is arguably quite different.

Lord Mustill was also uncomfortable with the acts/omissions distinction. He stated that the court's decision:

“. . . depends crucially on a distinction drawn by the criminal law between acts and omissions, and carries with it inescapably a distinction between, on the one hand what is often called 'mercy killing', where active steps are taken in a medical context to terminate the life of a suffering patient, and a situation such as the present where the proposed conduct has the aim for equally humane reasons of terminating the life of [the patient] by withholding from him the basic necessities of life. The acute unease which I feel about adopting this way through the legal and ethical maze is I believe due in an important part to the sensation that however much the terminologies may differ the ethical status of the two courses of action is for all relevant purposes indistinguishable". ${ }^{18}$

\section{Conclusion}

In many instances there may be good reasons of public policy for the strong stance which the law takes against positive acts which are intended to take life. It may be argued that it is of fundamental importance that patients are able to trust that their doctors will not harm them. Nevertheless, a comparison of the Cox case with the decisions affecting PVS patients leaves one with the feeling that the law's rigid approach is not always in line with the morality of the situation. It does seem ironic that the law treated Nigel Cox as a potential murderer, yet was prepared to hold that the doctors treating Mr Bland and Mrs Johnstone could allow them to be starved to death. It is worth repeating that Mrs Boyes was in excruciating pain, but $\mathrm{Mr}$ Bland and Mrs Johnstone were not. Mrs Boyes had only a few weeks to live, neither Mr Bland nor Mrs Johnstone was terminally ill. Lillian Boyes requested that her life be ended, the PVS patients were unable to express any opinion on the matter. Do terminally ill patients fear that their doctors will give them a quick death, if this is requested by the patients themselves? The public reaction to the case of Dr Cox suggests rather that patients fear that their suffering may be prolonged. It has been argued that:

"... if the same end, ie the patient's death, can be procured more humanely by a lethal injection . . . then it is not simply better medical practice to adopt this approach, we have a definite moral obligation to support it". ${ }^{19}$

Perhaps this is a moral obligation which ought to be given legal recognition. If the law is prepared to accept that, in some circumstances, a person's quality of life is so poor that he or she should not be kept alive then it should not shrink from considering that it may in fact be more humane for a doctor to administer a lethal injection which brings about a quick death, rather than to omit to feed that person.

Pamela $R$ Ferguson, $L L B, P h D$, is a Solicitor and Senior Lecturer in Law in the Department of Law, University of Dundee, Dundee, Scotland.

\section{References and notes}

1 R v Cox (1992) 12 B M L R 38.

$2 \mathrm{He}$ was also found guilty of serious professional misconduct by the GMC. See Dyer C. GMC tempers justice with mercy in Cox case. British Medical fournal 1992; 305: 1311.

3 An alternative state of mind for murder is that the accused intended to cause grievous bodily harm. See Smith JC, Hogan B. Criminal law. London: Butterworths, 1996: 357. Scots law is similar in requiring an intention to kill. See Gordon GH. The criminal law of Scotland. Edinburgh: W Green and Son Ltd, 1978: para 23-10.

4 R v Arthur British Medical fournal 1981; 283: 1340. Transcript 26 D-E, cited in Skegg PDG. Law, ethics and medicine. Oxford: Clarendon Press, 1984: 130, emphasis added.

5 Since Mrs Boyes had been cremated, the prosecuting authorities were unable to establish whether she had in fact died as a result of the doctor's injection, or from her pre-existing illness.

6 This assumes that the patient is an adult and is mentally competent. For a consideration of the law where the patient is not competent, see In re $\mathrm{T}$ (Adult: Refusal of Treatment) [1992] 3 W L R 782 and Gostin L. Consent to treatment: the incapable person. In Dyer C, ed. Doctors, patients and the law. Oxford: Blackwell Scientific Publications, 1992. For cases involving severely handicapped children, see $\operatorname{Re} J$ (a minor) (medical treatment) (1992) 9 B M L R 10, and Re C (a baby) [1996] 2 F L R 43 and [1996] Fam Law 533, discussed in Ferguson PR, Bissett-Johnson A. The withdrawal and withholding of medical treatment. Family Law 1996; 26: 563-65.

7 [1957] Crim L R 365.

8 Emphases added. A detailed account of the trial is given by Lord Devlin in Easing the passing: the trial of Dr Fohn Bodkin Adams. London: Faber and Faber Ltd, 1986. 
9 Hall C. Case highlights medical dilemma of terminally ill. The Independent 1990 Mar 16: 4.

10 Airedale NHS Trust v Bland [1993] A C 789; [1993] 1 All E R 821. [1994] 1 F C R 485.

11 Law Hospital NHS Trust v Lord Advocate, 1996 S L T 848. See also the Irish case of In the Matter of a Ward (1995) 2 I L R M 401.

12 See McLean SAM. End-of-life decisions and the law. Fournal of Medical Ethics 1996; 22: 261-2. For English law cases which have followed Bland, see Frenchay Healthcare Trust v S [1994] 1 W L R 601; [1994] 2 All E R 403; Swindon and Marlborough NHS Trust v S [1995] 3 Med L Rev 84 and Re G (Persistent Vegetative State) [1995] 2 F C RT 46.

13 [1993] AC 789 at $882 \mathrm{~A}$.

141996 SLT 848 at $852 \mathrm{~L}$.

15 See reference 14: 859F.

16 Jennett B. Letting vegetative patients die. British Medical fournal 1992; 305: 1305-6, at 1305.

17 See reference 13: 885G.

18 [1993] AC 789 at 887B-C.

19 Beloff J. Killing or letting die? Is there a valid moral dis- tinction? Newsletter. Voluntary Euthanasia Society of Scotland, 1993 Jan: 4-5, emphasis added.

\section{News and notes}

\section{Breast cancer: research without consent}

The UK Breast Cancer Coalition, representing women with breast cancer from all parts of the United Kingdom, is concerned that research without consent still continues in this country. They hope for a return to the spirit of the Nuremberg Code (1947) and its unequivocal statement that "the voluntary consent of the human subject is absolutely essential".

The board of the coalition has endorsed the following resolution: "We, members of the UK Breast Cancer Coalition, request the World Medical Assembly to consider our petition that the following clause be deleted from the Declaration of Helsinki, as amended in 1983:

'II Medical research combined with professional care (clinical research): 5 . If the physician considers it $\delta$ essential not to obtain informed consent, the specifice reasons for this proposal should be stated in the experimental protocol for transmission to the independent committee'."

For further comment contact Heather Goodare, Chair, Research Committee, UK Breast Cancer Coalition, Tel: 01403261674. 